\title{
Electrical power generation with PEM FC using hydrogen supply through $\mathrm{Mg}$-Ni reaction with water
}

\section{Dalius Girdzevičius,}

\section{Darius Milčius}

Center for Hydrogen

Energy Technologies,

Lithuanian Energy Institute,

Breslaujos str. 3,

LT-44403 Kaunas, Lithuania

E-maildalius.girdzevicius@lei.lt
Hydrogen is considered an energy vector of the future because of its potential use for clean energy generation. Portable electronic devices can be powered when hydrogen is supplied to fuel cells. In order to avoid massive equipment for hydrogen storage, direct hydrogen production can be achieved on-site during the reaction between metals/metal alloys/metal hydrides and water. Magnesium hydride offers great perspective for widespread applications as its weight yield of hydrogen reaches $6.4 \%$ according to the reaction with water and it can even increase to $15.2 \%$ if water produced in the fuel cell is used in the reaction again.

In the present work, $\mathrm{Mg}$ powder with the content of $\mathrm{Ni}$ was synthesized under low temperature hydrogen plasma conditions changing the DC magnetron current from 0.5 to $1 \mathrm{~A}$. As pure $\mathrm{Mg}$ powder was immersed into hydrogen plasma, the simultaneous hydrogenation process was ensured. Nickel was chosen as a catalyst capable to influence the growth of hydride. The process of electric power generation was investigated when reaction between modified $\mathrm{Mg}$ powder and water was applied to laboratory-built equipment consisting of a reactor for hydrogen production, gas dryer before $\mathrm{H}_{2}$ introduction to the fuel cell, fuel cell, load and energy meter. Solutions of acetic acid and sodium chloride were used as promoters during powder-water reactions. The characterisation of predicted magnesium hydride powder was done using scanning electron microscopy, electron dispersive spectroscopy and X-ray diffraction. $\mathrm{XRD}$ analysis showed only $\mathrm{Mg}, \mathrm{MgO}$ and Ni peaks indicating that hydrogen generation during powder-water reaction was evoked because of microgalvanic corrosion at $\mathrm{Mg}-\mathrm{Ni}$ intersections.

Key words: hydrogen generation, Mg-Ni powder, water, electrical power generation

\section{INTRODUCTION}

Constantly growing demand for portable multifunctional electronic devices leads to increased power requirements. Despite market needs for power sources in reasonable size and longevity, an autonomous electricity generation must be with high power density as well $[1,2]$.

High gravimetric energy density of hydrogen $(142 \mathrm{MJ} / \mathrm{kg})$ makes it an energy vector of the future. 
Because of its promising utilization for environmentally friendly energy generation without $\mathrm{CO}_{2}$ emissions, the development of an appropriate carrier where hydrogen would be safely stored is essential [2-4]. Hydrogen can be stored either in pressurized, cryogenic tanks or solids capable to ensure reversible absorption/desorption reaction of hydrogen with low energy exchange $[1,5,6]$. However, storage in high pressure or cryogenic tanks is not suitable for many hand-held applications as it requires massive equipment with additional safety fittings [6].

On the contrary, gas storage can be excluded if direct hydrogen production is achieved on-site during the reaction between metals, metal alloys, hydrides and water [3, 4, 6-9]. For example, aluminum, magnesium, lithium, zink, boron, beryllium or silicon are successfully applied for in-situ hydrogen generation using the previously mentioned water oxidation of light metals $[4,8]$.

Particular attention is paid to magnesium $(\mathrm{Mg})$ due to its low density, high capacity, reactivity and abundance in the earth $[10,11]$. Magnesium hydride $\left(\mathrm{MgH}_{2}\right)$ offers a great potential for widespread use as its weight yield of hydrogen reaches $6.4 \%$ and it can be increased up to $15.2 \%$ if water produced in a fuel cell (FC) is used in the reaction again [6]. Therefore, $\mathrm{Mg}$ and $\mathrm{MgH}_{2}$ are used for hydrogen production by the following reactions:

$$
\begin{aligned}
& \mathrm{Mg}+2 \mathrm{H}_{2} \mathrm{O} \rightarrow \mathrm{Mg}(\mathrm{OH})_{2}+\mathrm{H}_{2} \uparrow \Delta \mathrm{H}_{\mathrm{r}}= \\
& -354 \mathrm{~kJ} \mathrm{~mol}^{-1}[10], \\
& \mathrm{MgH}_{2}+2 \mathrm{H}_{2} \mathrm{O} \rightarrow \mathrm{Mg}(\mathrm{OH})_{2}+2 \mathrm{H}_{2} \uparrow \Delta \mathrm{H}_{\mathrm{r}}= \\
& -277 \mathrm{~kJ} \mathrm{~mol}^{-1}[6] .
\end{aligned}
$$

However, Mg does not show good reaction with water either at normal or elevated temperatures because of its native thin oxide layer that forms hydroxide in the presence of moisture preventing water to penetrate into the core and cause the start of hydrogen production. The same tendency is observed in case of $\mathrm{MgH}_{2}$ when powder-water reaction is hindered by the formation of a magnesium hydroxide layer reducing the rate of hydrogen production.

The kinetics of $\mathrm{Mg}$ and $\mathrm{MgH}_{2}$ hydrolysis can be enhanced when the formation of $\mathrm{Mg}(\mathrm{OH})_{2}$ is affected by decreasing $\mathrm{pH}$ value of the solution used during the reaction. Therefore, this process can be essentially improved using low concentration of acid or aqueous solution of sodium or potassium chloride causing increased rate of $\mathrm{Mg}$ corrosion $[8-10,12,13]$. Moreover, the corrosion rate of $\mathrm{Mg}$ to $\mathrm{Mg}^{2+}$ is enhanced when alloys with $\mathrm{Ni}, \mathrm{Fe}, \mathrm{Cu}$ or $\mathrm{Co}$ are used $[8,11]$. This is due to the fact that local galvanic acceleration of corrosion is achieved and corrosion resistance of $\mathrm{Mg}$ is reduced $[11,14,15]$. For instance, $\mathrm{Mg}$ with increased content of $\mathrm{Ni}$ (Mg-2.7 Ni) showed significantly faster hydrogen production compared with pure Mg. The difference in the rate of $\mathrm{H}_{2}$ production was 1300 times [11].

In the present work, Mg powder with the content of Ni was synthesized under low temperature hydrogen plasma conditions aiming to understand if hydride can be created. It is known that the dissociation barrier of $\mathrm{Mg}$ can be reduced by the catalyst of $\mathrm{Ni}$, and the formation of $\mathrm{Mg}$ $\mathrm{Ni}$ contact may influence the growth of hydride nucleation centres [16-19]. According to the reactions (1) and (2), magnesium hydride would generate more hydrogen than pure $\mathrm{Mg}$ during its on-site reaction with water. The modified $\mathrm{Mg}$ powder was characterized using scanning electron microscopy (SEM), electron dispersive spectroscopy (EDS) and X-ray diffraction (XRD). The process of electric power generation was investigated using laboratory-built equipment consisting of a reactor for hydrogen production, gas dryer before $\mathrm{H}_{2}$ introduction into the fuel cell, fuel cell, and load and energy meter.

\section{EXPERIMENTAL TECHNIQUES}

\section{Preparation of $\mathrm{Mg}-\mathrm{Ni}$ powder}

Ni films were deposited on Mg powder (315$630 \mu \mathrm{m}, 99 \%)$ using a magnetron sputtering system equipped with $99.99 \% \mathrm{Ni}$ target. The distance between the sample and the target was $7 \mathrm{~cm}$. The procedure was done at room temperature. $\mathrm{Ni}$ films were deposited changing the DC magnetron current (0.5 A, 0.75 A, 1 A) under hydrogen (AGA Gas AB, 99.999\%) atmosphere at $7 \mathrm{~Pa}$. Deposition was performed for $60 \mathrm{~min}$ for each sample.

A simultaneous hydrogenation process was applied to pure $\mathrm{Mg}$ powder when it was immersed into hydrogen plasma consisting of 
hydrogen ions, neutral atoms and molecules. In consequence, energetic ions were capable to get into the bulk of material and make bonds with $\mathrm{Mg}$ creating $\mathrm{MgH}_{2}$.

Figure 1 shows an experimental scheme of hydrogenation process used in this work. Experimental parameters are indicated in Table 1.

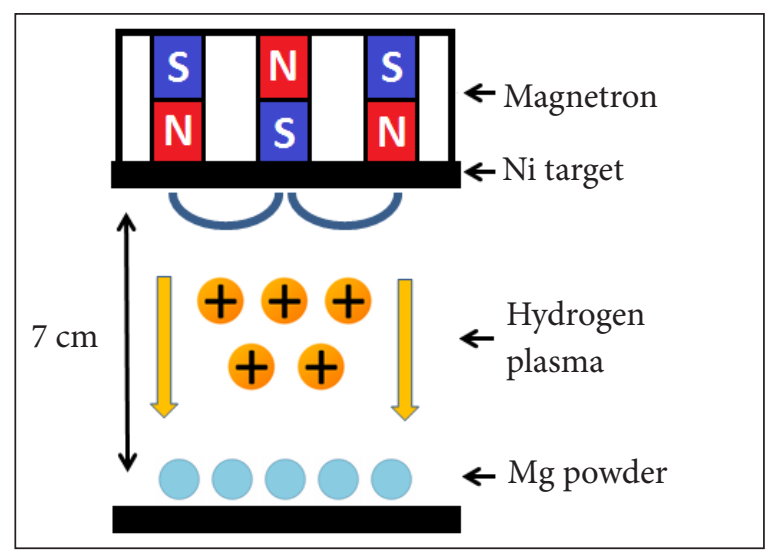

Fig. 1. Experimental scheme of hydrogenation process

Table 1. Experimental parameters

\begin{tabular}{c|c|c|c}
\hline Sample & Mg-Ni-0.5A & Mg-Ni-0.75A & Mg-Ni-1A \\
\hline Mg powder & \multicolumn{3}{|c}{ 315-630 $\mu \mathrm{m}, 99 \%$, ChemPUR } \\
\hline Ni target & $\begin{array}{c}\text { 4.00 “Diameter } \times \text { 0.125”Thick, 99.99\%, } \\
\text { Kurt J. Lesker }\end{array}$ \\
\hline Current & $0.5 \mathrm{~A}$ & $0.75 \mathrm{~A}$ & $1 \mathrm{~A}$ \\
\hline Pressure & $7 \mathrm{~Pa}$ \\
\hline $\begin{array}{c}\text { Time of } \\
\text { treatment }\end{array}$ & $60 \mathrm{~min}$ \\
\hline
\end{tabular}

\section{Characterization}

The surface morphology of $\mathrm{Mg}$ powder covered with $\mathrm{Ni}$ was characterized using a scanning electron microscope (Hitachi S-3400N). The elemental composition of the samples was identified by energy dispersive X-ray spectroscopy (EDX,
Bruker Quad 5040). Microstructural characterisation was carried out using the Bruker diffractometer D8. The diffractometer was used for $20^{\circ}<2 \theta<70^{\circ}$ with $\mathrm{Cu} \mathrm{Ka}$ radiation in $0.01^{\circ}$ steps. The EVA Search Match software was used for identification of peaks.

\section{Hydrogen generation}

Hydrogen generation based on the reaction between $\mathrm{Mg}$ powder and water was measured using an inverted burette $(250 \mathrm{~mL}$, tolerance $\pm 2 \mathrm{~mL}$ ) filled with water. An amount of produced $\mathrm{H}_{2}$ gas was indicated by the change of water level in the burette, and then the total volume of generated $\mathrm{H}_{2}$ was defined by integrating gas flow with time. In order to enhance hydrogen production, low concentration of acetic acid $\left(3 \% \mathrm{CH}_{3} \mathrm{COOH}\right)$ and aqueous solution of sodium chloride (5\% $\mathrm{NaCl}$ ) were used. In order to ensure an objective comparison of the results, an equal amount of $\mathrm{Mg}$ powder $(0.05 \mathrm{~g})$ was used in a volume of $30 \mathrm{~mL}$ of prepared solution during every experiment.

\section{Power generation}

The exploration of hydrogen production and its application for on-site electricity generation was carried out according to the scheme shown in Fig. 2. The equipment used in these experiments consisted of a reaction tank where $\mathrm{Mg}$ reaction with water took place, filtration unit, pressure valve ensuring constant $\mathrm{H}_{2}$ pressure supplied to the fuel cell, 1.5 W PEM fuel cell for energy generation, energy monitor from Horizon and resistance as a load of the system. Voltage alteration $U(t)$ and generated energy in $\mathrm{mWh}$ were measured during these experiments. In order to ensure an objective comparison of the results, an equal proportion of $\mathrm{Mg}$ powder and solution was used during experiments. The reaction took place when $0.1 \mathrm{~g}$ of $\mathrm{Mg}$ was introduced into $30 \mathrm{~mL}$ of prepared solution.

Fig. 2. Experimental scheme for energy generation based on $\mathrm{H}_{2}$ production during powder reaction with water

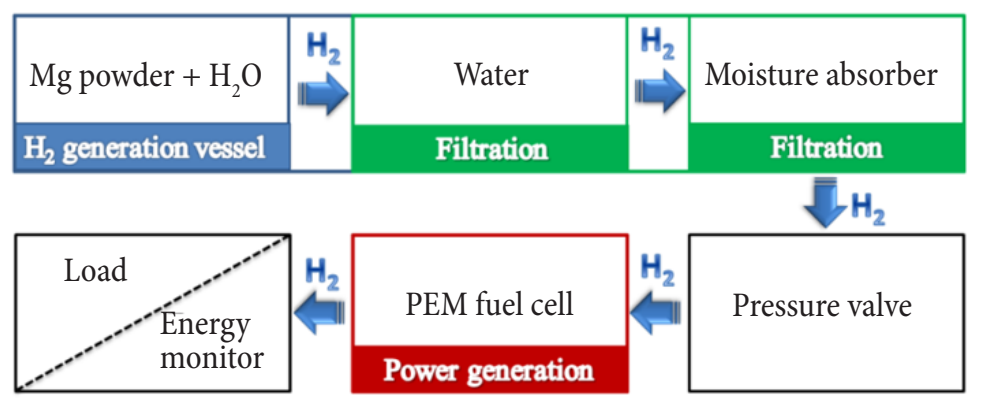




\section{RESULTS AND DISCUSSION}

\section{Characterisation of $\mathrm{Mg}-\mathrm{Ni}$ powder}

Figure 3 shows the surface morphology of pure $\mathrm{Mg}$ powder and its irregularities after hydrogen plasma treatment using a magnetron with $\mathrm{Ni}$ target as a source of plasma during the sputtering process. Ni films were deposited changing the DC magnetron current $(0.5 \mathrm{~A}, 0.75 \mathrm{~A}$, $1 \mathrm{~A}$ ). The SEM micrograph (Fig. 1a) of pure Mg demonstrates a relatively smooth surface without any precipitates. On the contrary, the images of $\mathrm{Mg}$-Ni powders (Fig. 1b-d) reveal non-uniform surface structure. However, no significant difference in morphological appearance is noticed among these Mg-Ni samples. The reason of this resemblance could be explained by the duration of a relatively long sputtering procedure (60 minutes) and properties of $\mathrm{Ni}$ itself demonstrating a high rate of sputtering in general [20].
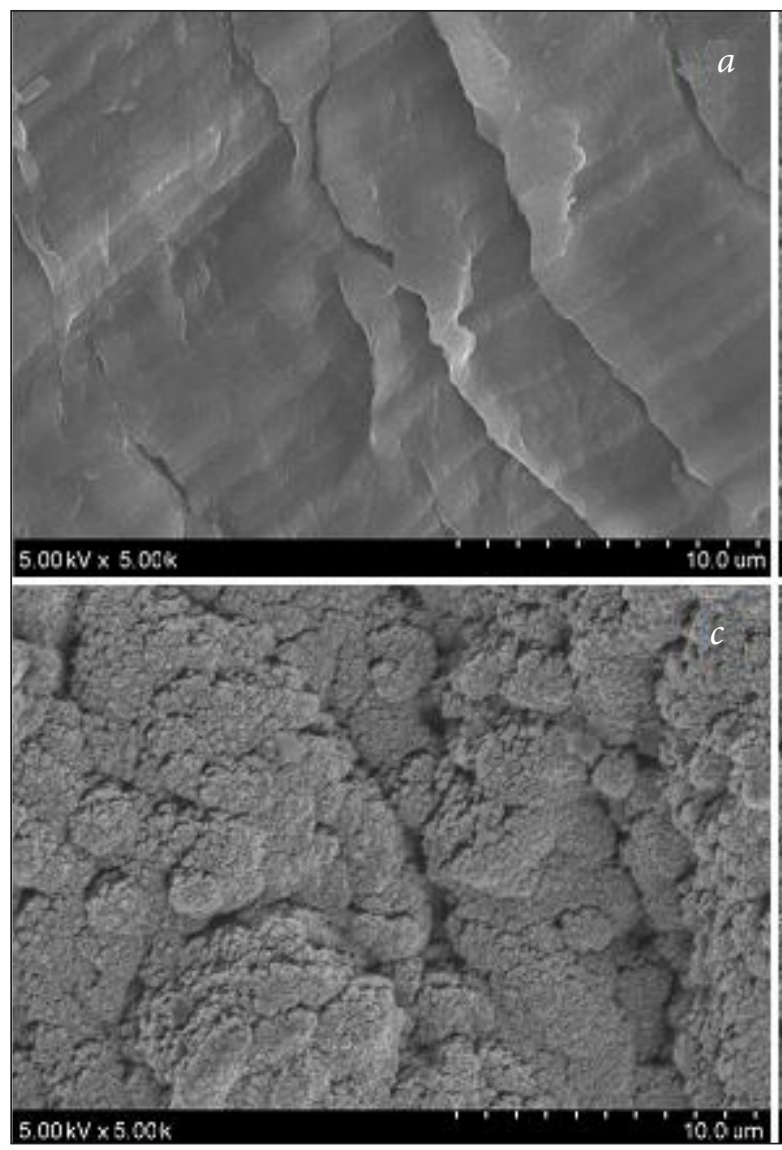

The elemental mapping analysis revealed uneven distribution of Ni (Fig. 4). The size of primary $\mathrm{Mg}$ powder $(315-630 \mu \mathrm{m})$ and spherical shape could be the reason for such inhomogenous distribution of a catalytic element, i. e. partial coverage of $\mathrm{Ni}$ is reached because of relatively large particles exposing only a part of their surface in plasma. This tendency is observed for all samples despite deposition conditions.

The XRD analysis of Mg-Ni samples showed only $\mathrm{Mg}, \mathrm{MgO}$ and Ni peaks. The formation of expected hydride was not observed when the sputtering of $\mathrm{Ni}$ was applied under low temperature hydrogen plasma. It is assumed that relatively higher temperature on the surface of powder can bring reversible chemical reactions when hydrogenation and decomposition take place simultaneously [21]. Therefore, at the end of sputtering nothing, except increase of Ni peak, was noticed. Despite the failure to form magnesium hydride, results showed successful deposition of $\mathrm{Ni}$ and its
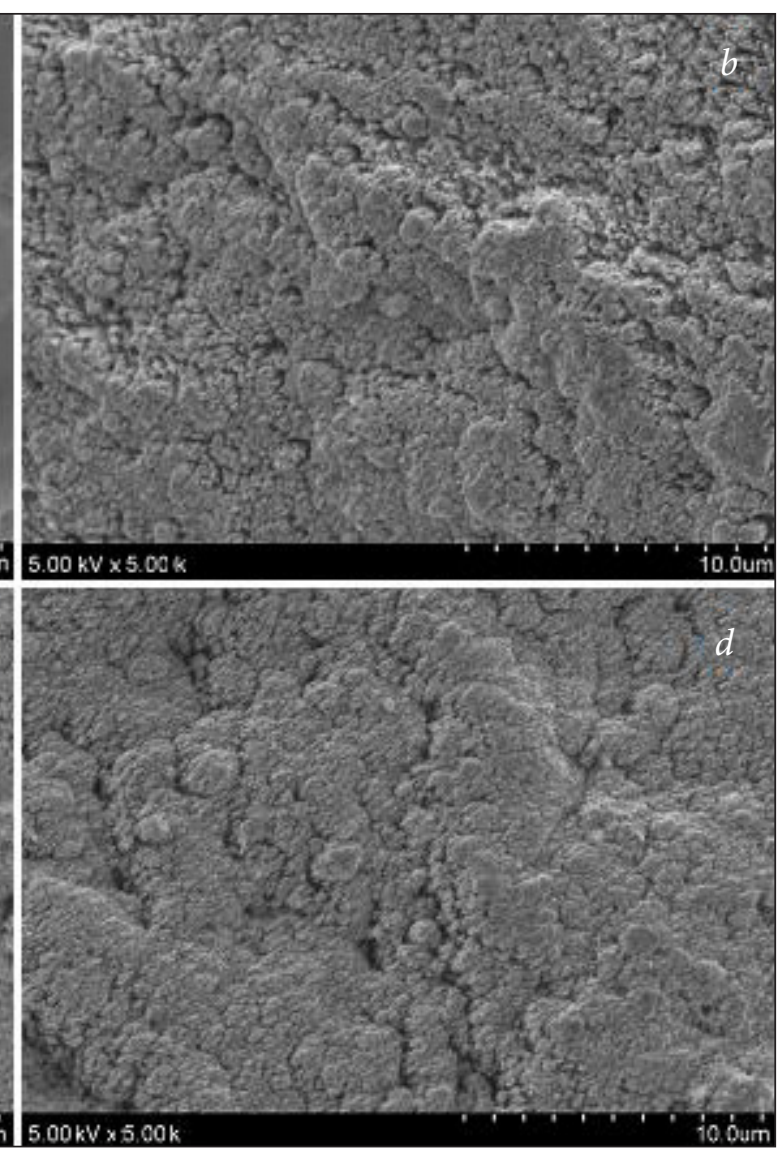

Fig. 3. SEM images of pure $\mathrm{Mg}(a)$ and its modifications after sputtering of Ni by changing the $D C$ magnetron current: $0.5 \mathrm{~A}(b), 0,75 \mathrm{~A}(c)$ and $1 \mathrm{~A}(d)$ 


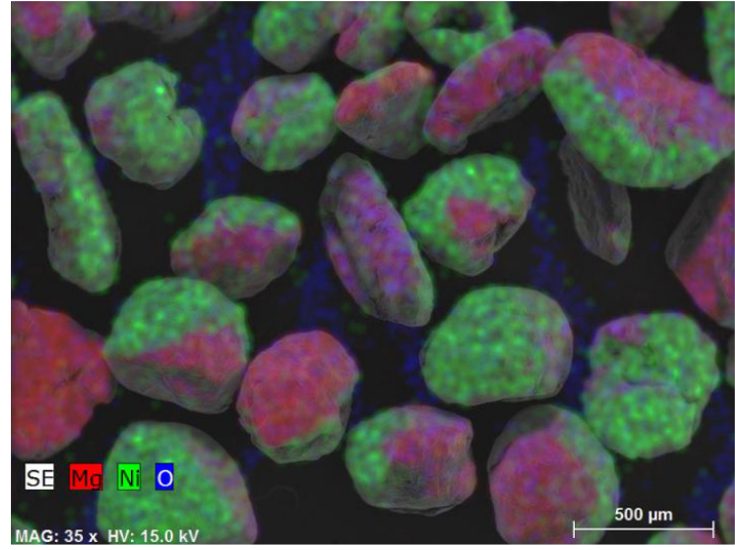

Fig. 4. Element mapping image of $\mathrm{Mg}-\mathrm{Ni}-1 \mathrm{~A}$ sample

growth by increasing the DC magnetron current from 0.5 A to $1 \mathrm{~A}$ (Fig. 5). It is clear that Ni deposition rate is increased by increasing the current. Therefore, XRD registered the growth of the cubic Ni phase which is marked as black triangles in Fig. 5.

Nevertheless, Mg powder covered with $\mathrm{Ni}$ can be implemented in the reaction with water for $\mathrm{H}_{2}$ generation. The micrographs of $\mathrm{Mg}-\mathrm{Ni}$ powder (Fig. $3 \mathrm{~b}-\mathrm{d}$ ) indicate a positive change in the specific surface area with increase of roughness compared to pure Mg. This result takes an important role during the reaction with water. Moreover, unevenly distributed Ni makes intersections with $\mathrm{Mg}$ creating centres where local galvanic corrosion can arise leading to the improvement of hydrogen generation. In general, microgalvanic corrosion is initiated because of the difference of $\mathrm{Mg}$ and $\mathrm{Ni}$ electrochemical potential, where these parameters are $-2.37 \mathrm{~V}$ and -0.25 , respectively [22].
Power generation using hydrogen generation during Mg-Ni powder reaction with water The second part of this study targets on exploration of hydrogen production and its application for electricity generation.

The $\mathrm{H}_{2}$ generation based on the reaction between $\mathrm{Mg}$-Ni powder and water was measured using an inverted burette filled with water. As pure water did not show any effect on hydrogen generation, reactions were done in two different solutions (promoters) in order to understand if it had any significant influence on the kinetics of $\mathrm{H}_{2}$ production. All reactions took place when $0.05 \mathrm{~g}$ of $\mathrm{Mg}$ was introduced into $30 \mathrm{~mL}$ of prepared solution.

First of all, $\mathrm{H}_{2}$ production was measured in the solution with low concentration of acetic acid $\left(3 \% \mathrm{CH}_{3} \mathrm{COOH}\right)$. Very similar hydrogen generation kinetics was observed among all Mg-Ni samples regardless of different sputtering conditions (Fig. 6 a). However, the efficiency of these reactions was higher compared with the process when pure Mg was introduced into water, i. e. such reactions demonstrated faster kinetics, and the total capacity of $\mathrm{H}_{2}$ was proportionately higher.

On the contrary, hydrogen production in aqueous solution of sodium chloride $(5 \% \mathrm{NaCl})$ varied more evidently depending on sputtering conditions (Fig. 6 b). Only pure Mg did not react with this salty liquid assuming that the key reason was the absence of $\mathrm{Mg}$ - $\mathrm{Ni}$ intersections inducing microgalvanic corrosion.

Summing up, current variation during DC magnetron sputtering had influence on hydrogen production rate. Moreover, it is important

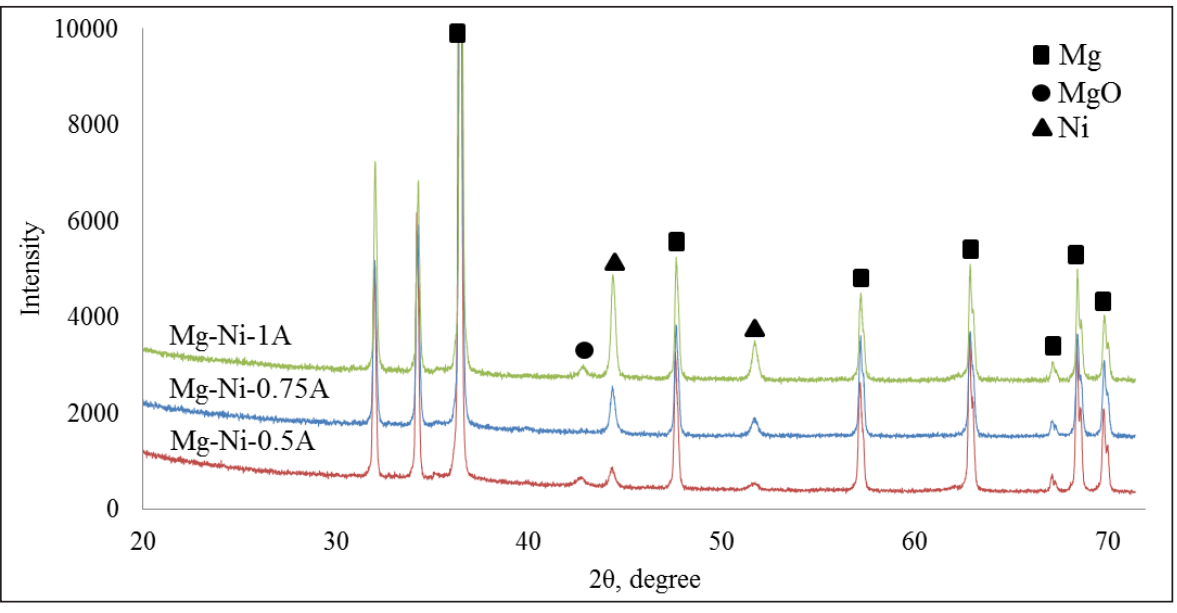

Fig. 5. XRD diffraction patterns of Mg-Ni samples 


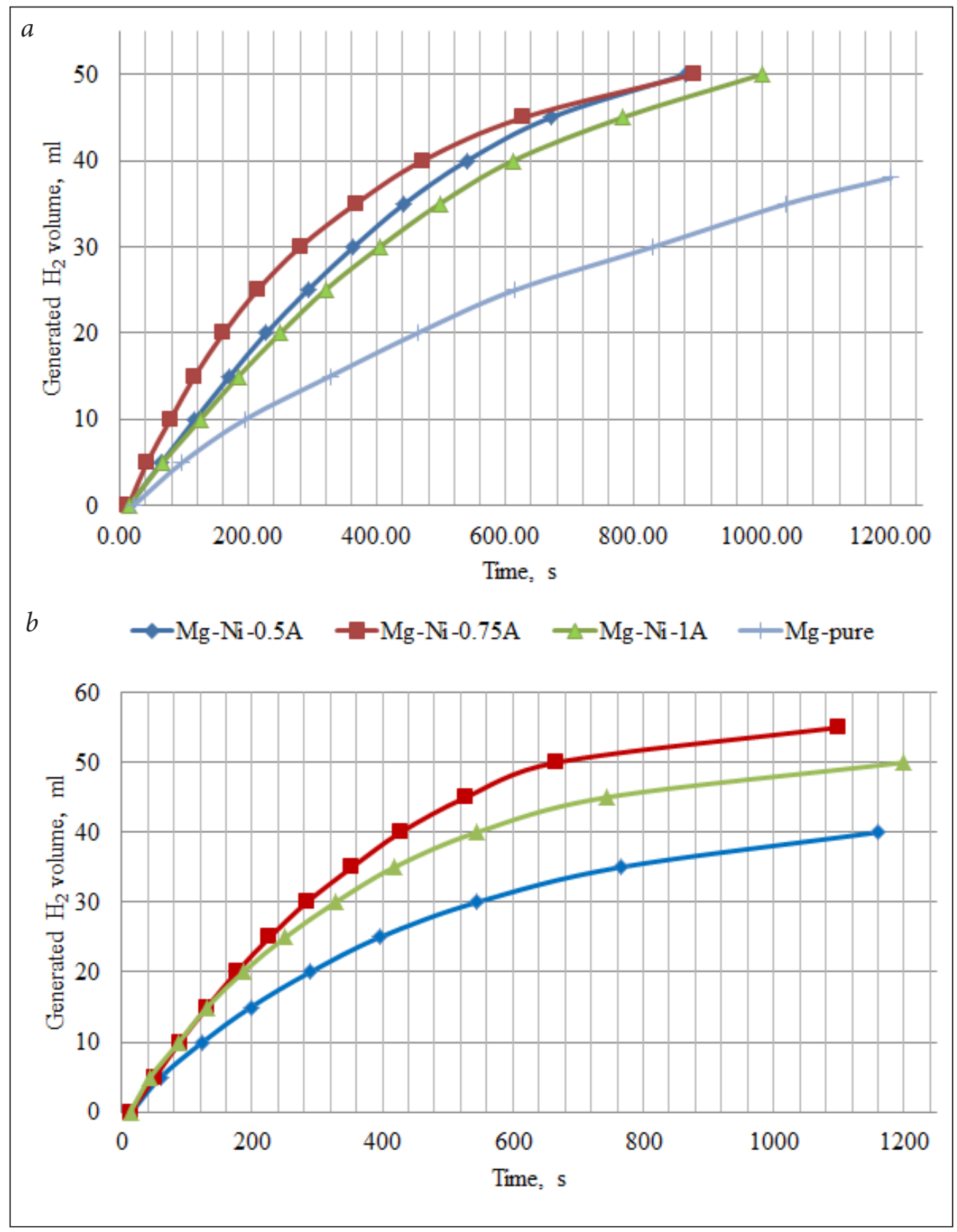

Fig. 6. Hydrogen generation during the reaction between $\mathrm{Mg}-\mathrm{Ni}$ powder and water using different promoters ( $a-3 \%$ of $\mathrm{CH}_{3} \mathrm{COOH} ; b-5 \%$ of $\mathrm{NaCl}$ ). Samples $\mathrm{Mg}-\mathrm{Ni}-0.5 \mathrm{~A}, \mathrm{Mg}-\mathrm{Ni}-0.75 \mathrm{~A}, \mathrm{Mg}-\mathrm{Ni}-1 \mathrm{~A}$ are prepared under different $\mathrm{DC}$ magnetron current during deposition of nickel $-0.5 \mathrm{~A}, 0.75 \mathrm{~A}, 1 \mathrm{~A}$, respectively

to notice that $\mathrm{Mg}-\mathrm{Ni}-0.75 \mathrm{~A}$ showed superior kinetics compared with other samples during all experiments. In this particular case, $\mathrm{MgO}$ peak was not observed in XRD analysis (Fig. 5). Therefore, the limiting barrier for the start of hydrogen generation was avoided.

Finally, the energy generation system was operated to confirm a possibility to implement $\mathrm{H}_{2}$ produced from the $\mathrm{Mg}-\mathrm{Ni}$ powder reaction with water. The voltage alteration in time $U(t)$ was measured during experiments. In this case, acetic acid was selected as a promoter. As mentioned previously, the reaction took place when $0.1 \mathrm{~g}$ of $\mathrm{Mg}$ was placed into $30 \mathrm{~mL}$ of prepared $3 \%$ $\mathrm{CH}_{3} \mathrm{COOH}$ solution.

According to the graph given in Fig. 7, the start of energy generation is very similar for all $\mathrm{Mg}$ Ni samples. Only pure Mg exhibits the delay of 


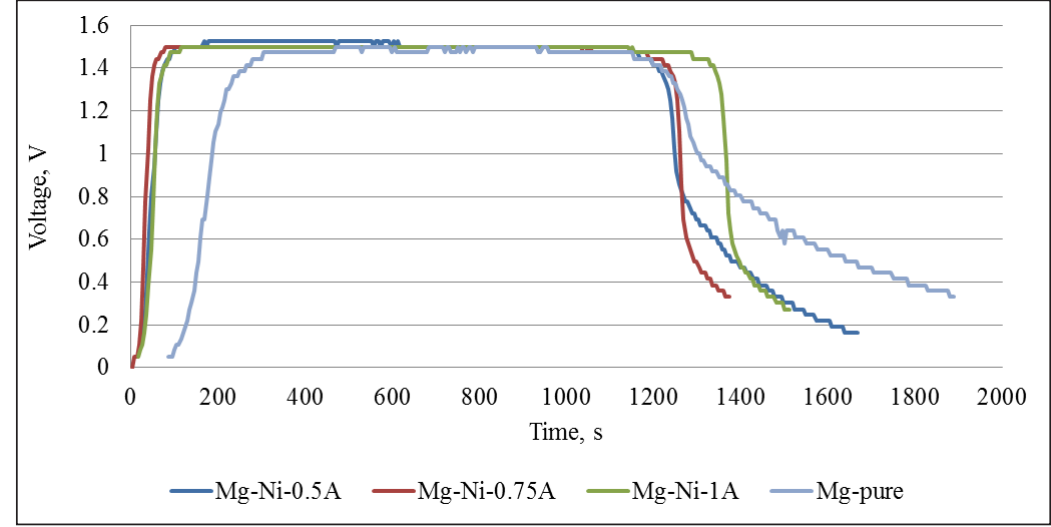

Fig. 7. Voltage alteration during energy generation. Samples $\mathrm{Mg}-\mathrm{Ni}-0.5 \mathrm{~A}, \mathrm{Mg}$ $\mathrm{Ni}-0.75 \mathrm{~A}, \mathrm{Mg}-\mathrm{Ni}-1 \mathrm{~A}$ are prepared under different $D C$ magnetron current during deposition of nickel $-0.5 \mathrm{~A}, 0.75 \mathrm{~A}, 1 \mathrm{~A}$, respectively the reaction. Based on SEM and EDS results presented in Figs. 3 and 4, it is evident that hydrogen production highly depends on morphological surface variation and appearance of $\mathrm{Ni}$ caused after treatment in plasma compared with pure $\mathrm{Mg}$ in general. Hence, a relatively smooth surface of pure $\mathrm{Mg}$ restricts the reaction with water.

Finally, the total amount of energy generated during $\mathrm{Mg}-\mathrm{Ni}$ powder reaction with water was identified (Fig. 8). As it was expected, the least amount of energy was generated during the reaction with pure $\mathrm{Mg}$ (17.22 $\mathrm{mWh}$ ). A very similar amount of generated energy was observed for $\mathrm{Mg}-\mathrm{Ni}-0.5 \mathrm{~A}$ (18.61 mWh) and $\mathrm{Mg}-\mathrm{Ni}-0.75 \mathrm{~A}$ $(18.89 \mathrm{mWh})$. Energy generation for all these samples took place for about 20 minutes. However, energy generation caused by $\mathrm{Mg}-\mathrm{Ni}-1 \mathrm{~A}$ reaction with water was measured for about 24 minutes and the total amount of produced energy reached $20.00 \mathrm{mWh}$.

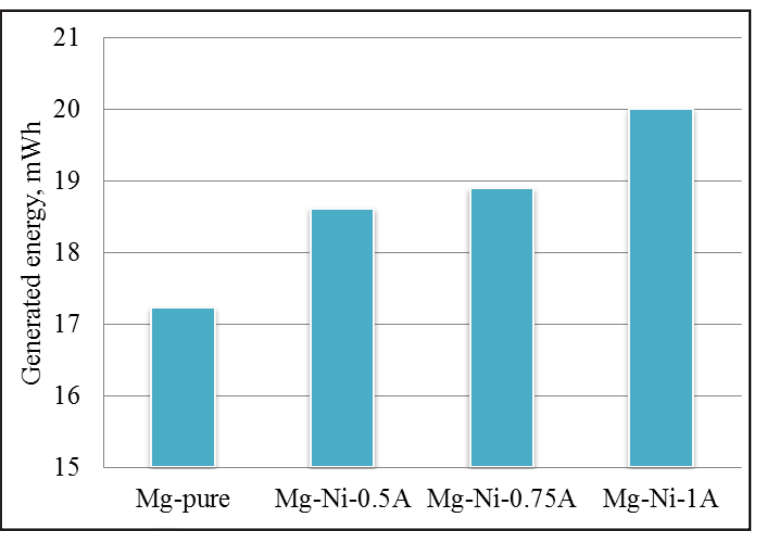

Fig. 8. Energy generation during $\mathrm{Mg}-\mathrm{Ni}$ powder reaction with water. Samples Mg-Ni-0.5A, Mg-Ni-0.75A, Mg-Ni-1A are prepared under different $D C$ magnetron current during deposition of nickel $-0.5 \mathrm{~A}$, $0.75 \mathrm{~A}, 1 \mathrm{~A}$, respectively
The results presented in Figs. 7 and 8 confirm the reaction's feasibility for on-site electricity generation. However, additional attention must be paid to the determination of the most appropriate ratio of powder to water used in the reaction. This assumption was raised because of disagreement in experimental results. In case of hydrogen production, $\mathrm{Mg}-\mathrm{Ni}-0.75 \mathrm{~A}$ demonstrated the highest rate of $\mathrm{H}_{2}$ generation. Therefore, it was expected that the total amount of produced energy would be observed for the same sample. However, Mg-Ni-1A was superior in this experiment. It is important to notice that $0.05 \mathrm{~g}$ of $\mathrm{Mg}$ powder were used during measurements of hydrogen production, and $0.1 \mathrm{~g}$ of $\mathrm{Mg}$ was introduced into water during investigation of energy generation when the volume and concentration of the solutions were kept as a constant.

\section{CONCLUSIONS}

$\mathrm{Ni}$ coatings were deposited onto $\mathrm{Mg}$ powder using magnetron sputtering technique under low temperature hydrogen plasma. It was expected to form hydride that could be implemented for hydrogen generation during reaction with water. However, nucleation centres of hydrides did not appear at Mg-Ni intersections. An assumption for such result could be related to a relatively higher temperature on the surface of powder during sputtering. In consequence, reversible chemical reactions of hydrogenation and decomposition could take place simultaneously.

Nevertheless, the synthesized Mg-Ni powder was investigated for in-situ hydrogen production and its integration for energy generation. This 
composition was confirmed as feasible for energy production on-demand, because hydrogen can be produced during microgalvanic corrosion taking place at $\mathrm{Mg}-\mathrm{Ni}$ intersections. The optimal energy generation can be achieved if an appropriate ratio of powder to water is found. Therefore, consistent experimentation is mandatory.

Received 5 April 2016 Accepted 15 May 2016

\section{References}

1. Ball N., Basile A., Veziroglu Nejat T. Compendium of Hydrogen Energy. Cambridge: Woodhead Publishing, 2016. 366 p.

2. Fernández-Moreno J., Guelbenzu G., Martín A. J., Folgado M. A., Ferreira-Aparicio P., Chaparro A. M. A portable system powered with hydrogen and one single air-breathing PEM fuel cell. Applied Energy. 2013. Vol. 109. P. 60-66.

3. Huanga M., Ouyang L., Wang H., Liu J., Zhu M. Hydrogen generation by hydrolysis of $\mathrm{MgH}_{2}$ and enhanced kinetics performance of ammonium chloride introducing. International Journal of Hydrogen Energy. 2015. Vol. 40. P. 6145-6150.

4. Yang W., Liu X., Liu J., Wang Z., Zhou J., Cen K. Thermogravimetric analysis of hydrogen production of Al-Mg-Li particles and water. International Journal of Hydrogen Energy. 2015. P. 1-8 (in press).

5. Hydrogen Storage (referred 1 March 2016). http://www.hydrogentrade.com/storage/

6. Tayeh T., Awad A. S., Nakhl M., Zakhour Silvain J.-F. Production of hydrogen from magnesium hydrides hydrolysis. International Journal of Hydrogen Energy. 2014. Vol. 39. P. 3109-3117.

7. How is hydrogen stored and generated for use with consumer electronic devices? (referred 3 March 2016). http://www.intelligent-energy.com/our-divisions/consumer-electronics/hydrogen-landscape/>

8. Kravchenko O. V., Sevastyanova L. G., Urvanov S. A., Bulychev B. M. Formation of hydrogen from oxidation of $\mathrm{Mg}, \mathrm{Mg}$ alloys and mixture with $\mathrm{Ni}, \mathrm{Co}, \mathrm{Cu}$ and $\mathrm{Fe}$ in aqueous salt solutions. International Journal of Hydrogen Energy. 2014. Article in press. P. 1-6.
9. Kravchenko O. V., Sevastyanova L. G., Genchel V. K., Bulychev B. M. Hydrogen generation from magnesium oxidation by water in presence of halides of transition and non-transition metals. International Journal of Hydrogen Energy. 2015. Vol. 40. P. 12072-12077.

10. Sun Q., Zou M., Guo X., Yang R., Huang H., Huang P., He X. A study of hydrogen generation by reaction of an activated $\mathrm{Mg}-\mathrm{CoCl}_{2}$ (magnesium-cobalt chloride) composite with pure water for portable applications. Energy. 2015. Vol. 79. P. 310-314.

11. Sekwon O., Kim M., Eom K., Kyung J., Kim D., Cho E., Kwon H. Design of MgeNi alloys for fast hydrogen generation from seawater and their application in polymer electrolyte membrane fuel cells. International Journal of Hydrogen Energy. 2016. Vol. 41. P. 5296-5303.

12. Quyang L., Ma M., Huang M., Duan R., Wang H., Sun L., Zhu M. Enhanced hydrogen generation properties of $\mathrm{MgH}_{2}$-based hydrides by breaking the magnesium magnesium hydroxide passivation layer. Energies. 2015. Vol. 8. P. 4237-4252.

13. Hiraki T., Hiroi S., Akashi T., Okinaka N., Akiyama T. Chemical equilibrium analysis for hydrolysis of magnesium hydride to generate hydrogen. International Journal of Hydrogen Energy. 2012. Vol. 37. P. 12114-12119.

14. Atrens A., Liu M., Zainal Abidin N. I., Song G.-L. Corrosion of Magnesium Alloys. Cambridge: Woodhead Publishing, 2011.656 p.

15. Atrens A., Song G.-L., Liu M., Shi Z., Cao F., Dargusch M. S. Review of recent developments in the field of magnesium corrosion. Advanced Engineering Materials. 2015. Vol. 4. P. 400-453.

16. Zaluska A., Zaluski L., Strom-Olsen J. O. Nanocrystalline magnesium for hydrogen storage. Journal of Alloys and Compounds. 1999. Vol. 288. P. 217-225.

17. Krishnan G., Negrea R. F., Ghica C., Brink G. H., Kooi B. J., Palasantzas G. Synthesis and exceptional thermal stability of $\mathrm{Mg}$-based bimetallic nanoparticles during hydrogenation. Nanoscale. 2014. Vol. 6. P. 11963-11970.

18. Tien H.-Y., Tanniru M., Wu C.-Y., Ebrahimi F. Effect of hydride nucleation rate on the hydrogen capacity of Mg. International Journal of $\mathrm{Hy}$ drogen Energy. 2009. Vol. 34. P. 6343-6349. 
19. Giusepponi S., Celino M. The role of nickel catalyst in hydrogen desorption from $\mathrm{MgH}_{2}$ : A DFT study. International Journal of Hydrogen Energy. 2015. Vol. 40. P. 9326-9334.

20. Chang S. A., Skolnik M. B., Altman C. High rate sputtering deposition of nickel using dc magnetron mode. Journal of Vacuum Science \& Technology A. 1986. Vol. 4. P. 413-416.

21. Felderhoff M., Bogdanovic B. High temperature metal hydrides as heat storage materials for solar and related applications. International Journal of Molecular Sciences. 2009. Vol. 10. P. 325-344.

22. Standard Reduction Potentials in Aqueous Solution at $25^{\circ} \mathrm{C}$ (referred 4 March 2016). http://goo. gl/tK0Pde

\section{Dalius Girdzevičius, Darius Milčius}

\section{ELEKTROS ENERGIJOS GENERAVIMAS PANAUDOJANT PEM KURO ELEMENTUS, KAI TIEKIAMAS VANDENILIS YRA GAUNAMAS Mg-Ni REAKCIJOS SU VANDENIU METU}

\section{Santrauka}

Dèl potencialaus vandenilio panaudojimo aplinkai draugiškos energijos generavimo procese šis elementas yra laikomas vienu iš ateities energijos vektorių. Nešiojamiems prietaisams elektros energija gali būti už-

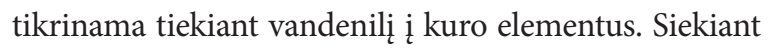
išvengti masyvios įrangos, skirtos vandeniliui saugoti, siūlomas vandenilio dujų generavimas pagal poreikį, panaudojant metalų, jų lydinių, metalo hidridų reakcijas su vandeniu. Magnio hidridas pasižymi plačiomis taikymo galimybèmis dèl santykinai didelès vandenilio išeigos pagal masę. Remiantis magnio hidrido reakcija su vandeniu, išeiga gali siekti 6,4 \%, o dar kartą panaudojus iš kuro elemento gautą vandenị - 15,2 \%.

Šiame darbe Mg milteliai su Ni priemaišomis buvo gauti panaudojus žematemperatūrinị magnetroninị nusodinimą vandenilio dujų plazmos aplinkoje, keičiant prie magnetrono prijungto nuolatinès srovès šaltinio srovę nuo 0,5 iki $1 \mathrm{~A}$. Mg milteliams sąveikaujant su vandenilio dujų plazma buvo užtikrinamas vienalaikis magnetroninis $\mathrm{Ni}$ nusodinimas ir miltelių hidrinimas. Visų eksperimentų metu išlaikytas nekintantis darbinis slègis $(7 \mathrm{~Pa})$ ir poveikio plazmoje laikas (60 min.).

Nikelis pasirinktas kaip katalizatorius, galintis pagerinti hidrido susidarymą, sukuriant nukleacijos centrus. Elektros energijos generavimas buvo tiriamas laboratorijoje sukonstruotu stendu, kuriame vyko plazmoje modifikuotų Mg miltelių reakcija su vandeniu. Siekiant paspartinti šią sąveiką kaip aktyvatoriai buvo naudojami acto rūgšties ir natrio chlorido tirpalai. Vandenilio gamybos bei elektros energijos generavimo eksperimentai patvirtino, kad $\mathrm{MgO}$ nebuvimas, morfologiniai paviršiaus pakitimai, $\mathrm{Ni}$ priemaišos bei tinkamas miltelių ir vandens santykis lemia vykstančių reakcijų efektyvumą.

Plazmoje modifikuotų magnio miltelių charakterizavimas buvo atliekamas panaudojant skenuojantị elektronų mikroskopą, rentgeno spindulių energijos dispersijos spektroskopą ir rentgeno spindulių difraktometrą. Skenuojančiu elektroniniu mikroskopu buvo stebimi morfologiniai $\mathrm{Mg}$ miltelių paviršiaus pakitimai lyginant su plazmoje nepaveiktais milteliais. Naudojant rentgeno spindulių energijos dispersijos spektroskopą nustatytas nehomogeniškas $\mathrm{Ni}$ pasiskirstymas, priklausantis nuo pradinių miltelių dydžio ir formos. Atliekant rentgeno struktūrinę bandinių analizę identifikuotos tik Mg, MgO ir Ni smailès, indikuojančios, kad vandenilio generavimas, panaudojant miltelių reakciją su vandeniu, yra sukeltas mikrogalvaninès korozijos Mg-Ni sandūros taškuose.

Raktažodžiai: vandenilio gamyba, $\mathrm{Mg}-\mathrm{Ni}$ milteliai, vanduo, elektros energijos generavimas 